\title{
INTEGRASI METODE FMEA DAN TOPSIS UNTUK MENGANALISIS RISIKO KECELAKAAN PADA PROSES FRAME AND FORK WELDING
}

\author{
Rama Putra Perdana, Evi Yuliawati \\ Jurusan Teknik Industri \\ Institut Teknologi Adhi Tama Surabaya \\ just_rama@rocketmail.com ; evi_y_widodo@yahoo.com
}

\begin{abstract}
ABSTRAK
PT. Insera Sena, produsen sepeda merk Polygon, telah mendunia dengan berbagai macam sepeda produksinya seperti city bikes, trekking, MTB, full-suspension, hard-tail bikes, downhill, BMX dan masih banyak lagi. Dalam proses produksinya, proses frame and fork welding adalah proses dimana berpotensi tinggi terjadi risiko kecelakaan. Hal ini dikarenakan terdapat banyak mesin yang digunakan pada proses frame and fork welding yang dapat membahayakan tenaga kerja. Risiko kecelakaan adalah bagian yang tidak terpisahkan dalam setiap aktivitas perusahaan, sehingga cara terbaik yang dapat dilakukan adalah mengantisipasi dan melindungi diri terhadap risiko yang berpotensi besar terjadi pada perusahaan. Saat ini PT. Insera Sena sedang melaksanakan proyek pembentukan tim safety yang memiliki fungsi yang berkaitan dengan kesehatan dan keselamatan kerja tenaga kerja. Dalam rangka mencegah terjadinya kecelakaan dan timbulnya biaya yang tinggi akibat risiko kecelakaan maka diperlukan evaluasi dan analisis untuk memperbaiki atau menghilangkan kegagalan sebelum kinerja sistem menurun.

Penelitian ini memanfaatkan integrasi metode FMEA dan TOPSIS untuk mengetahui tingkat terjadinya risiko kecelakaan yang terjadi pada proses frame and fork welding PT. Insera Sena, melalui nilai RPI. Kemudian dengan menggunakan diagram pareto akan ditentukan risiko kecelakaan yang potensial terjadi pada proses frame and fork welding.

Hasil penelitian menunjukkan bahwa risiko kecelakaan yang potensial terjadi pada proses frame and fork welding PT. Insera Sena ada 5 yaitu : tergores mesin gerinda dengan nilai RPI sebesar 0,928, mata terkena gram pada proses polishing dengan nilai RPI sebesar 0,668, mata terkena percikan gerinda dengan nilai RPI sebesar 0, 661, mata terkena gram pada proses cutting dengan nilai RPI sebesar 0, 657 dan mata terkena gram pada mesin champer/taper dengan nilai RPI sebesar 0, 641. Berikut adalah usulan kepada PT. Insera Sena yang dapat dilakukan sebagai upaya pencegahan terjadinya risiko kecelakaan potensial, yaitu : memberikan pelatihan pada pekerja, memperketat peraturan, memberikan APD dan pengaman pada mesin yang ada.
\end{abstract}

Kata kunci : risiko kecelakaan, risk priority index (RPI), Failure Mode Effect and Analysis (FMEA), TOPSIS

\section{PENDAHULUAN}

Meningkatknya persaingan perusahaan dan tuntutan konsumen dewasa ini, mengharuskan perusahaan untuk dapat fokus pada upaya peningkatan kinerja, perbaikan kualitas produk dan peningkatan efisiensi. Salah satu hambatan yang seringkali muncul dalam meningkatkan kualitas dan produktivitas adalah terjadinya failure (kegagalan) pada sistem.

Indonesia boleh berbangga diri karena memiliki perusahaan sepeda yang telah mendunia, yaitu PT. Insera Sena, sebagai produsen sepeda merk Polygon. Berbagai macam sepeda telah diproduksi perusahaan ini, antara lain city bikes, trekking, MTB, full-suspension, hard-tail bikes, downhill, BMX dan masih banyak lagi. Dengan didukung peralatan yang lengkap dan canggih serta memenuhi standar Internasional, PT. Insera Sena sudah mendapat kepercayaan oleh dunia sebagai produsen sepeda yang diakui kualitasnya. Hal ini dapat di lihat dari jutaan sepeda yang telah diekspor ke lebih dari 30 negara di 5 benua di dunia. Pengembangan sumber daya manusia dan berbagai hal teknis telah mengisi tahun-tahun perjalanan Polygon sebagai salah satu merk sepeda kelas dunia. Sepeda Polygon selalu memberikan kinerja optimal bagi pengendaranya dan ini merupakan esensi terpenting dalam bersepeda. 
Dalam proses produksi pembuatan sepeda di PT. Insera Sena, seringkali tenaga kerja kurang hati-hati dalam pekerjaan dan berpotensi membahayakan kesehatan dan keselamatan kerjanya. Proses yang paling berpotensi terjadinya risiko kecelakaan tersebut terdapat pada proses frame and fork welding karena pada proses tersebut banyak menggunakan mesin yang dapat membahayakan tenaga kerja dibandingkan dengan proses yang lain. Disamping itu, saat ini PT. Insera Sena juga sedang dalam proyek pembentukan tim safety yang nantinya memiliki fungsi untuk hal-hal yang berkaitan dengan kesehatan dan keselamatan kerja tenaga kerja. Oleh karena itu untuk mencegah terjadinya kecelakaan dan timbulnya biaya yang tinggi akibat risiko tersebut, maka diperlukan evaluasi dan analisis risiko untuk memperbaiki atau menghilangkan kegagalan sebelum kinerja sistem menurun.

Dalam rangka untuk menghindari segala bentuk kegagalan dalam proses produksi dan pengembangan maka digunakan metode FMEA yang diintegrasikan dengan TOPSIS sebagai upaya pencegahan. Integrasi metode tersebut juga dapat memperkirakan bentuk kegagalan dan menemukan cara yang paling ekonomis untuk menghentikan kegagalan tersebut.

Teknik FMEA diimplementasikan untuk mengidentifikasi bentuk-bentuk potensi kegagalan, menentukan dampaknya terhadap produksi, dan mengidentifikasikan tindakan untuk mengurangi kegagalan [1]. Standar evaluasi FMEA didasarkan pada tingkat keparahan/ keseriusan (S), kejadian (O), dan deteksi (D) untuk setiap kejadian risiko. Perkalian nilai S, O dan D akan memperoleh nilai Risk Priority Number (RPN). RPN adalah ukuran yang digunakan untuk menilai risiko dalam mengidentifikasi risiko kegagalan potensial terkait dengan desain atau proses. Namun, teknik FMEA ini memiliki kelemahan pada hasil RPN yang memiliki nilai yang sama tetapi mungkin menimbulkan representasi risiko yang berbeda. Untuk mengurangi kelemahan yang terdapat pada metode FMEA maka digunakan metode TOPSIS untuk mengatasi permasalahan tersebut.

Metode TOPSIS merupakan teknik pemilihan alternatif yang mempertimbangkan jarak terpendek dari titik idealnya dan jarak terjauh dengan titik negatifnya [2]. Asumsi dasar pada metode ini adalah bahwa solusi terbaik harus sedekat mungkin ke solusi ideal dan terjauh dari solusi ideal negatif. Pendekatan TOPSIS memiliki beberapa kelebihan diantaranya [3] : (1) logikanya bersifat sederhana dan mudah dipahami, (2) proses perhitungannya mudah, (3) alternatif terbaik yang terpilih merupakan model matematika sederhana, (4) penilaian terpenting berada pada prosedur yang diperbandingkan.

Maka, dengan menggunakan integrasi metode FMEA dan TOPSIS diharapkan kinerja sistem pada proses frame and fork welding PT. Insera Sena dapat meningkat.

\section{LANDASAN TEORI}

\section{A. KAJIAN PUSTAKA}

Dalam penelitian yang dilakukan oleh Sachdeva et all (2009) yang berjudul Multi-Factor Mode Critically Analysis Using TOPSIS, teknik baru berdasarkan metode FMEA yang dimodifikasi bersama dengan TOPSIS diusulkan untuk mengevaluasi risiko maintenance. Teknik ini dikembangkan untuk mengatasi batas-batas dari RPN. Teknik ini telah secara khusus disesuaikan dengan menyederhanakan prosedur penilaian risiko dan memungkinkan untuk evaluasi yang benar pada data yang bersangkutan.

\section{B. MANAJEMEN RISIKO}

Manajemen risiko adalah proses pengukuran atau penilaian risiko serta pengembangan strategi pengelolaannya. Strategi yang dapat diambil antara lain adalah memindahkan risiko kepada pihak lain, meghindari risiko, mengurangi efek negatif risiko, dan menampung sebagian atau semua konsekuensi risiko tertentu. Manajemen risiko tradisional terfokus pada risiko-risiko yang timbul oleh penyebab fisik atau legal (seperti bencana alam atau kebakaran, kematian serta tuntutan hukum).

Manajemen risiko bertujuan untuk mengelola risiko sehingga organisasi bisa bertahan, atau barangkali mengoptimalkan risiko ketidakpastian [4]. Manajemen risiko pada dasarnya dilakukan melalui proses-proses berikut ini : 
- Identifikasi risiko

- Evaluasi dan pengukuran risiko

- Pengelolaan risiko

\section{FMEA}

Failure Mode and Effect Analysis (FMEA) / Mode Kegagalan dan Analisis Efek adalah metodologi untuk menganalisis potensi masalah keandalan atau peristiwa yang tidak diinginkan di awal siklus pengembangan yang lebih mudah untuk mengambil tindakan untuk mengatasi masalah, dengan demikian meningkatkan kehandalan melalui desain.

FMEA diimplementasikan untuk mengidentifikasi bentuk-bentuk potensi kegagalan, menentukan dampaknya terhadap produksi dan mengidentifikasikan tindakan untuk mengurangi kegagalan [1]. Mode Kegagalan dan Efek Analisis sebagai alat perencanaan pada pengembangan proses, produk, atau layanan.

\section{TOPSIS}

Metode TOPSIS merupakan sebuah teknik berdasarkan pada konsep pemilihan alternatif yang mempunyai jarak terpendek dari titik idealnya dan memiliki jarak terjauh dengan titik negatifnya [2]. Asumsi dasarnya adalah bahwa solusi terbaik harus sedekat mungkin ke solusi ideal dan yang terjauh dari solusi ideal negatif. Pendekatan TOPSIS memiliki beberapa kelebihan diantaranya [3] : (1) logikanya bersifat sederhana dan mudah dipahami, (2) proses perhitungannya mudah, (3) alternatif terbaik yang terpilih merupakan model matematika sederhana, dan (4) penilaian terpenting berada pada prosedur yang diperbandingkan.

Berikut adalah langkah-langkah metode TOPSIS [2] :

1. Membangun matriks perbandingan kriteria pada TOPSIS.

TOPSIS dimulai dengan membangun sebuah matriks keputusan,

$$
X=\left[x_{i j}\right]
$$

2. Normalisasi matriks perbandingan kriteria asli.

Digunakan persamaan (Deng et all., 2002 dalam Sachdeva et all., 2009) untuk mengubah setiap elemen $\left[x_{i j}\right]$ yang diberikan di bawah ini :

$$
r_{i j}=\frac{x_{i j}}{\sum_{i=1}^{n} x_{i j}}
$$

3. Perhitungan bobot setiap perbandingan kriteria.

Perhitungan perbandingan berat masing-masing kriteria didasarkan pada perhitungan nilai entropi dan kemudian mengubahnya menjadi berat digambarkan dalam dua langkah berikut :

a. Hitung nilai entropi setiap kriteria $C_{1}, C_{2}, \ldots C_{n}$.

Bobot setiap kriteria dihitung menggunakan konsep entropi [2]. $e_{j}$ mewakili entropi dari kriteria $j^{\text {th }}$.

$$
e_{j}=-\frac{1}{\ln n} \sum_{i=1}^{n} r_{i j} \ln r_{i j}
$$

Dimana 1/ln $n$ merupakan konstanta dan membuat nilai $e_{j}$ diantara 0 (nol) dan 1 (satu). 
b. Perhitungan bobot $w_{1}, w_{2}, w_{3}, \ldots . w_{n}$ setiap kriteria.

Bobot obyektif untuk setiap kriteria didapat :

$$
w_{j}=\frac{1-e_{j}}{\sum_{j=1}^{m}\left(1-e_{j}\right)}
$$

4. Penetapan solusi ideal positif $\left(v^{+}\right)$dan solusi ideal negatif $\left(v^{-}\right)$untuk masingmasing perbandingan kriteria.

Dalam rangka untuk menurunkan indeks kinerja dari setiap kriteria yang digunakan untuk perbandingan, penting untuk menghitung solusi ideal positif $v^{+}$dan solusi ideal negatif $v^{-}$dari masing-masing kriteria.

$$
\begin{gathered}
v^{+}=\left(\max \left(r_{i 1}\right),\left(\max \left(r_{i 2}\right), \ldots \ldots,\left(\max \left(r_{i n}\right)\right)\right.\right. \\
=\left(v_{1}^{+}, v_{2}^{+}, \ldots \ldots, v_{n}^{+}\right) \\
v^{-}=\left(\min \left(r_{i 1}\right),\left(\min \left(r_{i 2}\right), \ldots \ldots,\left(\min \left(r_{i n}\right)\right)\right.\right. \\
=\left(v_{1}^{-}, v_{2}^{-}, \ldots \ldots, v_{n}^{-}\right)
\end{gathered}
$$

5. Perhitungan jarak pada setiap kriteria antara solusi ideal positif $v^{+}$dan solusi ideal negatif $v^{-}$.

Untuk menghitung jarak euclidean g dari setiap alternatif ke $v_{1}^{+}$dan $v_{1}^{-}$menggunakan persamaan berikut :

$$
\begin{aligned}
& d^{+}=\sqrt{\sum_{j=1}^{m} w_{j}\left(v_{j}^{+}-r_{i j}\right)^{2}} \\
& d^{-}=\sqrt{\sum_{j=1}^{m} w_{j}\left(r_{i j}-v_{j}^{-}\right)^{2}}
\end{aligned}
$$

6. Perhitungan relatif Risk Priority Index (RPI) dari solusi ideal.

Peringkat akhir dari alternatif-alternatif didapat dengan mengacu pada nilai relatif kedekatan terhadap solusi ideal. Untuk setiap kriteria yang dibandingkan, perhitungan Risk Priority Index (RPI) dapat dihitung dengan menggunakan rumus :

$$
R P I=\frac{d_{i}^{-}}{d_{i}^{+}+d_{i}^{-}}
$$




\section{METODOLOGI PENELITIAN}

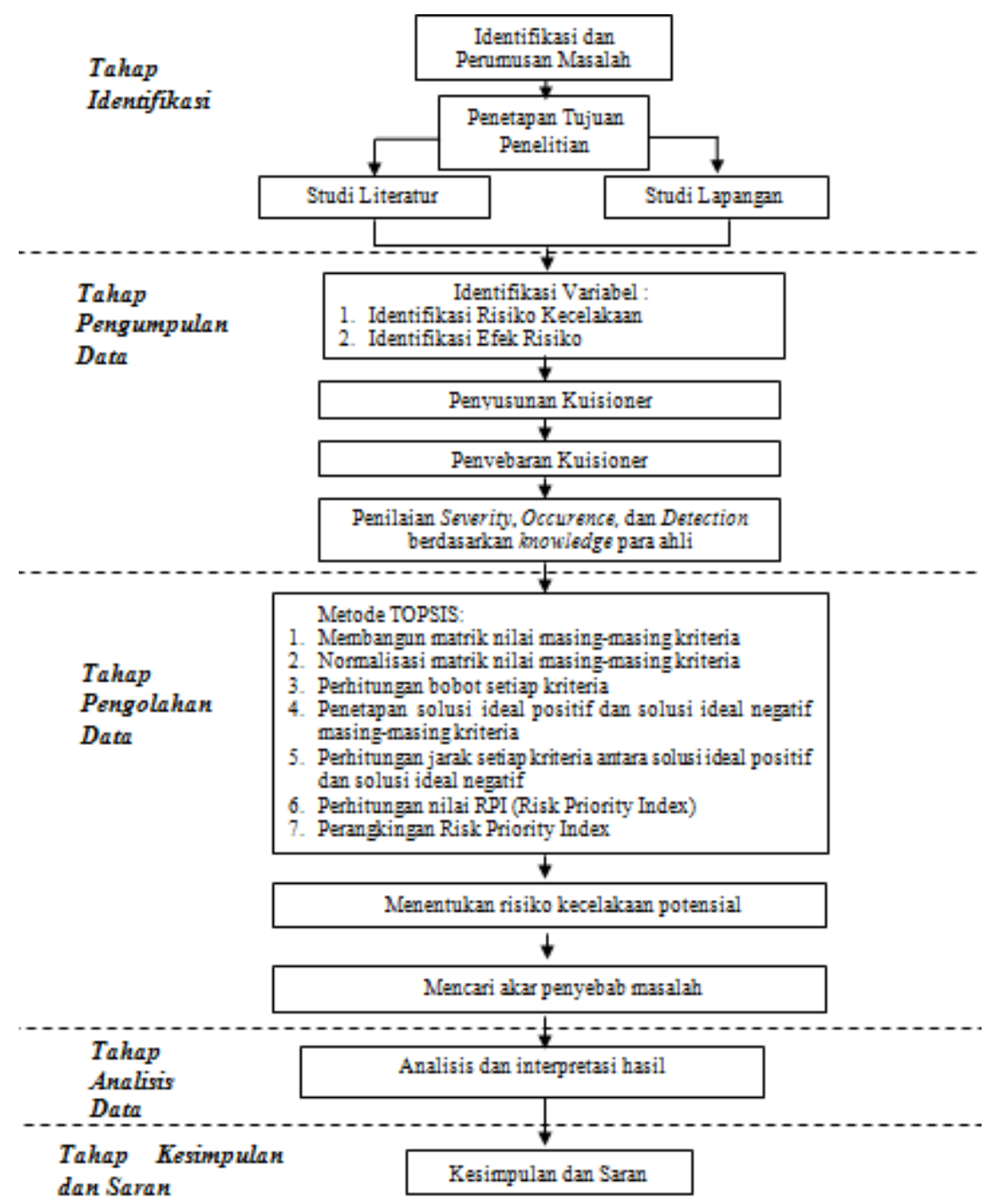

Gambar 1. Metodologi Penelitian

\section{HASIL DAN PEMBAHASAN}

Pada tahap awal dilakukan identifikasi risiko kecelakaan serta efek risiko yang terdapat pada proses frame and fork welding PT. Insera Sena. Proses ini adalah tahap awal dari pembuatan sepeda di PT. Insera Sena. Dari hasil identifikasi terdapat 43 risiko kecelakaan dan efek risiko, yang dapat dilihat pada tabel berikut :

Tabel 1. Hasil Identifikasi Risiko Kecelakaan dan Efek Risiko

\begin{tabular}{|l|l|l|l|l|}
\hline No & \multicolumn{1}{|c|}{ Proses } & \multicolumn{2}{|c|}{$\begin{array}{c}\text { Risiko Kecelakaan } \\
\text { (Failure Mode) }\end{array}$} & \multicolumn{1}{c|}{$\begin{array}{c}\text { Efek Risiko } \\
\text { (Failure Effect) }\end{array}$} \\
\hline 1 & $\begin{array}{l}\text { Proses } \\
\text { Cutting }\end{array}$ & F1 & Kejatuhan pipa & Memar \\
\cline { 3 - 5 } & F2 & $\begin{array}{l}\text { Tangan terjepit mesin } \\
\text { cutting }\end{array}$ & Terluka \\
\cline { 3 - 4 } & F3 & $\begin{array}{l}\text { Terkena putaran gergaji } \\
\text { mesin cutting }\end{array}$ & \\
\hline
\end{tabular}




\begin{tabular}{|c|c|c|c|c|}
\hline & & F4 & $\begin{array}{l}\text { Mata terkena gram pada } \\
\text { proses cutting }\end{array}$ & $\begin{array}{l}\text { Cedera pada mata (bisa } \\
\text { menyebabkan kebutaan) }\end{array}$ \\
\hline & & F5 & $\begin{array}{l}\text { Mesin yang bising pada } \\
\text { mesin cutting }\end{array}$ & Menganggu pendengaran \\
\hline 2 & \multirow[t]{2}{*}{$\begin{array}{l}\text { Proses } \\
\text { Forming }\end{array}$} & F6 & $\begin{array}{l}\text { Tangan terjepit mesin } \\
\text { press hidrolic }\end{array}$ & Memar, patah tulang \\
\hline & & F7 & $\begin{array}{l}\text { Tangan terbentur mesin } \\
\text { roll }\end{array}$ & Memar \\
\hline \multirow[t]{4}{*}{3} & \multirow[t]{4}{*}{$\begin{array}{l}\text { Proses } \\
\text { Pemetasan }\end{array}$} & F8 & $\begin{array}{l}\text { Mesin yang bising pada } \\
\text { mesin noching }\end{array}$ & Menganggu pendengaran \\
\hline & & F9 & $\begin{array}{l}\text { Tergores alloy yang telah } \\
\text { terpotong }\end{array}$ & \multirow[t]{2}{*}{ Terluka } \\
\hline & & F10 & $\begin{array}{l}\text { Terkena putaran mesin } \\
\text { noching }\end{array}$ & \\
\hline & & F11 & $\begin{array}{l}\text { Mata terkena gram pada } \\
\text { proses pemetasan }\end{array}$ & $\begin{array}{l}\text { Cedera pada mata (bisa } \\
\text { menyebabkan kebutaan) }\end{array}$ \\
\hline 4 & $\begin{array}{l}\text { Proses } \\
\text { Bending }\end{array}$ & F12 & $\begin{array}{l}\text { Tangan terjepit mesin } \\
\text { punch }\end{array}$ & Memar, patah tulang \\
\hline \multirow[t]{2}{*}{5} & \multirow[t]{2}{*}{$\begin{array}{l}\text { Proses } \\
\text { Drilling }\end{array}$} & F13 & $\begin{array}{l}\text { Terkena putaran mesin } \\
\text { drilling }\end{array}$ & Terluka \\
\hline & & F14 & $\begin{array}{l}\text { Mata terkena gram pada } \\
\text { proses drilliing }\end{array}$ & $\begin{array}{l}\text { Cedera pada mata (bisa } \\
\text { menyebabkan kebutaan) }\end{array}$ \\
\hline \multirow[t]{4}{*}{6} & \multirow{4}{*}{$\begin{array}{l}\text { Proses } \\
\text { Brazing }\end{array}$} & F15 & \multirow[t]{2}{*}{ Gas meledak } & Kebakaran \\
\hline & & F16 & & Luka-luka, memar, cedera \\
\hline & & F17 & $\begin{array}{l}\text { Terkena api dari las pada } \\
\text { proses brazing }\end{array}$ & Terluka \\
\hline & & F18 & $\begin{array}{l}\text { Sinar las pada proses } \\
\text { brazing }\end{array}$ & $\begin{array}{l}\text { Cedera pada mata (bisa } \\
\text { menyebabkan kebutaan) }\end{array}$ \\
\hline \multirow[t]{4}{*}{7} & \multirow[t]{4}{*}{$\begin{array}{l}\text { Proses } \\
\text { Polishing }\end{array}$} & F19 & $\begin{array}{l}\text { Mata terkena gram pada } \\
\text { proses polishing }\end{array}$ & $\begin{array}{l}\text { Cedera pada mata (bisa } \\
\text { menyebabkan kebutaan) }\end{array}$ \\
\hline & & F20 & $\begin{array}{l}\text { Mesin yang bising pada } \\
\text { mesin polish }\end{array}$ & Menganggu pendengaran \\
\hline & & F21 & Menghirup serbuk & Saluran pernafasan terganggu \\
\hline & & F22 & $\begin{array}{l}\text { Tangan terkena putaran } \\
\text { mesin poles }\end{array}$ & Terluka \\
\hline \multirow[t]{5}{*}{8} & \multirow[t]{5}{*}{$\begin{array}{l}\text { Proses } \\
\text { Welding }\end{array}$} & F23 & $\begin{array}{l}\text { Sinar las pada proses } \\
\text { welding }\end{array}$ & $\begin{array}{l}\text { Cedera pada mata (bisa } \\
\text { menyebabkan kebutaan) }\end{array}$ \\
\hline & & F24 & $\begin{array}{l}\text { Terkena api dari las pada } \\
\text { proses welding }\end{array}$ & Terluka \\
\hline & & F25 & $\begin{array}{l}\text { Menghirup uap dari } \\
\text { proses las }\end{array}$ & Saluran pernafasan terganggu \\
\hline & & F26 & Tersengat listrik & Tersetrum \\
\hline & & F27 & Kabel terbakar & Kebakaran \\
\hline \multirow[t]{3}{*}{9} & \multirow[t]{3}{*}{$\begin{array}{l}\text { Proses } \\
\text { Treatment T4 }\end{array}$} & F28 & $\begin{array}{l}\text { Kulit terkena larutan } \\
\text { solfen untuk proses } \\
\text { treatment }\end{array}$ & Penyakit pada kulit \\
\hline & & F29 & $\begin{array}{l}\text { Kejatuhan benda berat } \\
\text { dari crane }\end{array}$ & \multirow[t]{2}{*}{ Memar, cedera, patah tulang } \\
\hline & & F30 & $\begin{array}{l}\text { Terpeleset pada area } \\
\text { sekitar T4 }\end{array}$ & \\
\hline
\end{tabular}




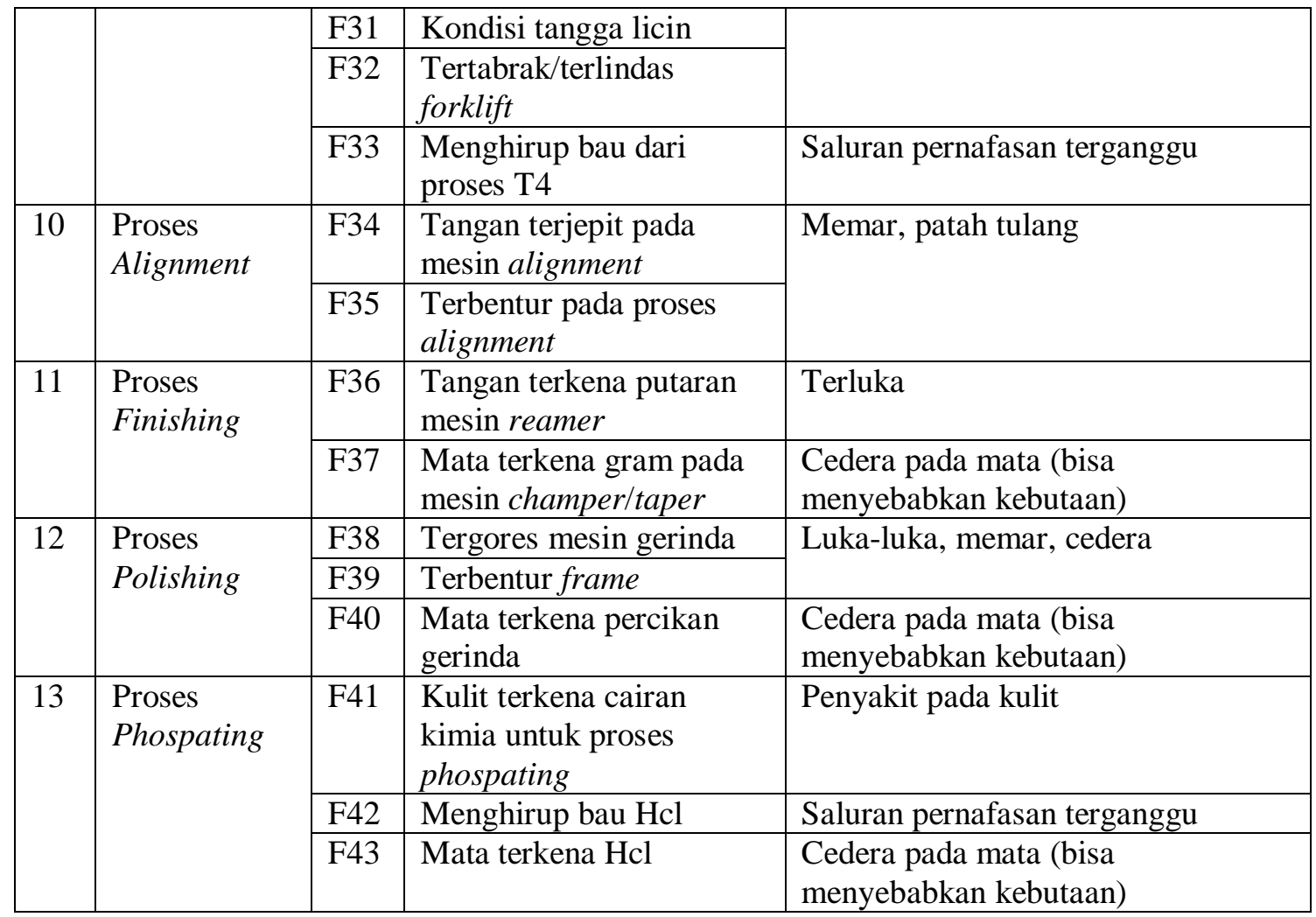

Risiko kecelakaan yang teridentifikasi tersebut kemudian dipakai sebagai variabel dalam kuisioner untuk mendapatkan nilai kriteria severity, occurence dan detection untuk setiap variabel. Setelah mendapatkan nilai untuk masing-masing kriteria pada masing-masing variabel, langkah selanjutnya adalah melakukan perhitungan dengan menggunkan TOPSIS. Berikut adalah urutan langkah untuk mendapatkan nilai Risk Priority Index :

Tabel 2. Tabel Perhitungan Risk Priority Index

\begin{tabular}{|c|c|c|c|c|}
\hline $\begin{array}{c}\text { Failure } \\
\text { Mode }\end{array}$ & $\boldsymbol{d}^{+}$ & $\boldsymbol{d}^{-}$ & $\begin{array}{c}\mathbf{R P I}= \\
\frac{\boldsymbol{d}_{\boldsymbol{i}}^{-}}{\boldsymbol{d}_{\boldsymbol{i}}^{+}+\boldsymbol{d}_{\boldsymbol{i}}^{-}}\end{array}$ & Ranking \\
\hline F1 & 0,034417071 & 0,010802403 & 0,238888302 & 32 \\
\hline F2 & 0,039333462 & 0,005886012 & 0,130165417 & 42 \\
\hline F3 & 0,037732274 & 0,0074872 & 0,165574681 & 38 \\
\hline F4 & 0,015496297 & 0,029723177 & 0,657309207 & 4 \\
\hline F5 & 0,018015232 & 0,027204242 & 0,60160456 & 9 \\
\hline F6 & 0,035395385 & 0,009824089 & 0,217253507 & 34 \\
\hline F7 & 0,030598327 & 0,014621147 & 0,323337404 & 25 \\
\hline F8 & 0,018491763 & 0,026727711 & 0,591066384 & 10 \\
\hline F9 & 0,024879559 & 0,020339915 & 0,449804334 & 19 \\
\hline F10 & 0,038608608 & 0,006610866 & 0,146195119 & 41 \\
\hline F11 & 0,01626494 & 0,028954535 & 0,640311174 & 6 \\
\hline F12 & 0,034475264 & 0,01074421 & 0,2376014 & 33 \\
\hline F13 & 0,035687496 & 0,009531978 & 0,21079365 & 36 \\
\hline F14 & 0,01670853 & 0,028510944 & 0,630501443 & 7 \\
\hline
\end{tabular}




\begin{tabular}{|c|c|c|c|c|}
\hline F15 & 0,033091437 & 0,012128038 & 0,268203861 & 29 \\
\hline F16 & 0,03396777 & 0,011251704 & 0,2488243 & 31 \\
\hline F17 & 0,027330072 & 0,017889402 & 0,395612786 & 23 \\
\hline F18 & 0,031538167 & 0,013681307 & 0,302553436 & 27 \\
\hline F19 & 0,015019767 & 0,030199707 & 0,667847383 & 2 \\
\hline F20 & 0,017571642 & 0,027647832 & 0,611414276 & 8 \\
\hline F21 & 0,019169891 & 0,026049584 & 0,576070023 & 12 \\
\hline F22 & 0,041626564 & 0,00359291 & 0,079454936 & 43 \\
\hline F23 & 0,031246056 & 0,013973419 & 0,309013293 & 26 \\
\hline F24 & 0,026853541 & 0,018365934 & 0,406150976 & 21 \\
\hline F25 & 0,020435179 & 0,024784295 & 0,548088973 & 16 \\
\hline F26 & 0,035676649 & 0,009542826 & 0,211033536 & 35 \\
\hline F27 & 0,033383548 & 0,011835926 & 0,261744004 & 30 \\
\hline F28 & 0,019393747 & 0,025825727 & 0,571119579 & 13 \\
\hline F29 & 0,037905847 & 0,007313627 & 0,161736224 & 39 \\
\hline F30 & 0,027596136 & 0,017623339 & 0,389728959 & 24 \\
\hline F31 & 0,027304024 & 0,01791545 & 0,396188816 & 22 \\
\hline F32 & 0,038305649 & 0,006913825 & 0,152894852 & 40 \\
\hline F33 & 0,020468119 & 0,024751355 & 0,547360527 & 17 \\
\hline F34 & 0,026504419 & 0,018715055 & 0,413871573 & 20 \\
\hline F35 & 0,018579737 & 0,026639738 & 0,589120906 & 11 \\
\hline F36 & 0,032503657 & 0,012715817 & 0,281202236 & 28 \\
\hline F37 & 0,016232 & 0,028987474 & 0,641039619 & 5 \\
\hline F38 & 0,003213223 & 0,042006251 & 0,928941612 & 1 \\
\hline F39 & 0,021362194 & 0,02385728 & 0,527588627 & 18 \\
\hline F40 & 0,015311878 & 0,029907596 & 0,661387526 & 3 \\
\hline F41 & 0,019870279 & 0,025349196 & 0,560581389 & 17 \\
\hline F42 & 0,019991588 & 0,025227886 & 0,557898703 & 13 \\
\hline F43 & 0,037050026 & 0,008169448 & 0,180662161 & 30 \\
\hline & & & & \\
\hline
\end{tabular}

Setelah mendapatkan ranking untuk masing-masing variabel, maka langkah selanjutnya adalah menentukan variabel potensial dengan menggunakan diagram pareto. Hasil dari penggambaran konsep pareto 80/20 memperlihatkan risiko kecelakaan yang memiliki dampak terbesar. Konsep ini mengasumsikan bahwa pada umumnya 80\% permasalahan yang ada disebabkan oleh $20 \%$ penyebab. Diagram ini membantu kita untuk memfokuskan usaha kepada 20\% penyebab tersebut dibandingkan dengan mengerjakan 80\% penyebab lain yang memiliki dampak kecil terhadap permasalahan. Risiko kecelakaan yang masuk dalam 20\% dampak terbesar akan dicari solusi efektif untuk meminimalkan efek risiko yang timbul karena risiko kecelakaan tersebut.

Berikut merupakan penggambaran diagram pareto untuk risiko kecelakaan yang terjadi pada proses frame and fork welding PT. Insera Sena : 


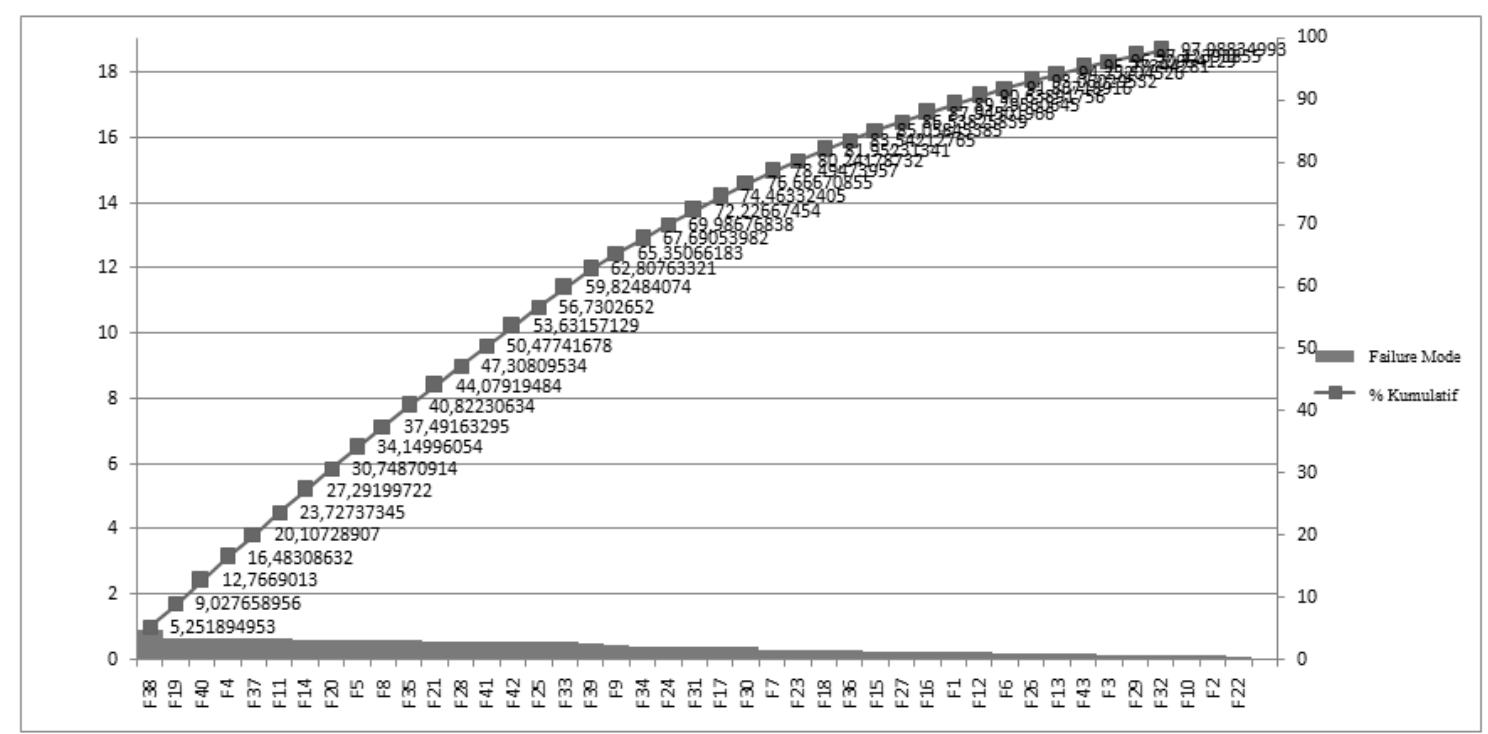

Gambar 2. Diagram Pareto Risiko Kecelakaan

Dari hasil pengolahan data dengan diagram pareto didapatkan lima risiko kecelakaan poensial yang masuk dalam $20 \%$ penyebab, yaitu :

1. Tergores mesin gerinda (risiko kecelakaan no.38)

2. Mata terkena gram pada proses polishing (risiko kecelakaan no.19)

3. Mata terkena percikan gerinda (risiko kecelakaan no.40)

4. Mata terkena gram pada proses cutting (risiko kecelakaan no.4)

5. Mata terkena gram pada mesin champer/taper (risiko kecelakaan no.37)

Setelah risiko kecelakaan potensial teridentifikasi, selanjutnya dilakukan pencarian penyebab munculnya risiko yang masuk dalam 20\% penyebab diagram pareto dengan diagram Ishikawa. Hasil dari diagram Ishikawa merupakan solusi alternatif perbaikan yang dapat megurangi efek terjadinya risiko kecelakaan potensial. Solusi alternatif perbaikan tersebut adalah sebagai berikut :

- Memperketat peraturan.

- Memberikan banner atau poster besar mengenai K3 disekitar lingkungan kerja

- Memberikan pelatihan dan wawasan yang baru mengenai teknologi pada alat produksi terhadap pekerja.

- Memberikan alat pelindung diri pada pekerja berupa safety glass, sarung tangan, penutup lengan dan earplug.

- Pemasangan kaca pengaman atau pelat plastik tembus pandang pada bagian depan mesin yang ada yaitu, mesin cutting, polihing dan champer/taper.

- Menambah ventilasi pada sekitar lingkungan kerja.

\section{KESIMPULAN DAN SARAN}

Dari hasil penelitian yang telah dilakukan terkait dengan analisis risiko kecelakaan potensial pada proses Frame and Fork Welding PT. Insera Sena, maka dapat ditarik kesimpulan sebagai berikut :

1. Hasil identifikasi awal diperoleh 43 risiko kecelakaan dan efek risiko pada proses Frame and Fork Welding PT. Insera Sena.

2. Terdapat lima risiko kecelakaan potensial yang masuk dalam $20 \%$ penyebab diagram pareto yaitu:

a. Tergores mesin gerinda (risiko kecelakaan no.38)

b. Mata terkena gram pada proses polishing (risiko kecelakaan no.19) 
c. Mata terkena percikan gerinda (risiko kecelakaan no.40)

d. Mata terkena gram pada proses cutting (risiko kecelakaan no.4)

e. Mata terkena gram pada mesin champer/taper (risiko kecelakaan no.37)

3. Solusi alternatif perbaikan untuk meminimalkan risiko kecelakaan potensial adalah sebagai berikut :

- Memperketat peraturan.

- Memberikan banner atau poster besar mengenai K3 disekitar lingkungan kerja

- Memberikan pelatihan dan wawasan yang baru mengenai teknologi pada alat produksi terhadap pekerja.

- Memberikan alat pelindung diri pada pekerja berupa safety glass, sarung tangan, penutup lengan dan earplug.

- Pemasangan kaca pengaman atau pelat plastik tembus pandang pada bagian depan mesin yang ada yaitu, mesin cutting, polihing dan champer/taper.

- Menambah ventilasi pada sekitar lingkungan kerja.

\section{DAFTAR PUSTAKA}

[1] Crow, A. 2002. Pengelolaan Risiko. Yogayakarta: Nur Cahya

[2] Sachdeva, A., Kumar, D., Kumar, P. 2009, Multi-Factor Mode Critically Analysis Using TOPSIS. International Journal of Industrial Enineering , Vol. 5, No. 8 pp 1-9.

[3] Wang, T. C., Chang, T. H. 2006, Application of TOPSIS in Evaluating Initial Trainning Aircraft Under A Fuzzy Environment, Expert System with Aplication, Vol. 36, pp. 1195-1207.

[4] Pressman, Roger S. 2002, Rekayasa Perangkat Lunak Pendekatan Praktisi (Buku I). Yogayakarta : Andi Offset. 